\title{
The Effect of Streptozotocin-induced Diabetes on the Early Steps of Glucagon Action in Isolated Rat Liver Cells
}

\author{
H. Chamras ${ }^{1}$, M. Fouchereau-Peron, and G. Rosselin \\ Unité de Recherche de Diabétologie et d'Etudes Radio-Immunologiques des Hormones Protéiques (INSERM, U. 55; CNRS ERA 494), \\ Hôpital Saint-Antoine, Paris, France
}

Summary. This study was undertaken to investigate the effect of experimental diabetes on the early steps of glucagon action. The binding of glucagon and glucagon-stimulated cyclic AMP accumulation in the presence of a potent phosphodiesterase inhibitor (IBMX, $0.1 \mathrm{mmol} / \mathrm{l}$ ) were studied in liver cells isolated from control and streptozotocin-induced $(65 \mathrm{mg} / \mathrm{kg})$ diabetic rats. Comparative studies of insulin binding indicated that hepatocytes of diabetic rats bound twice as much ${ }^{125}$ I-insulin $(10.8 \pm 2.0 \%)$ as those of control rats $(5.7 \pm 1.3 \%)$. Scatchard analysis and the competition plots of the data suggested that this was due to an increased number of receptors rather a change in their affinity. No significant change was observed in ${ }^{125}$ I-glucagon binding of diabetic liver cells $(5.8 \pm 0.5 \%)$ as compared to controls $(6.8 \pm 0.4 \%)$. The number of molecules of glucagon bound to high and low affinity binding sites of control liver cells was $(51 \pm 2) \times 10^{3}$ and $(1300 \pm$ 134) $\times 10^{3}$ sites/cell, respectively. The corresponding numbers in streptozotocin-treated rats were $(45 \pm 5)$ $\times 10^{3}$ and $(1000 \pm 167) \times 10^{3}$ sites/cell, respectively. Cyclic AMP response to concentrations of glucagon below $1 \mathrm{nmol} / 1$ was significantly lower in diabetics than in normals: for $0.3 \mathrm{nmol} / 1$ and $0.6 \mathrm{nmol} / \mathrm{l}$ of glucagon, cyclic AMP production was $48 \pm 7 \mathrm{pmol} /$ $10^{6}$ cells and $78 \pm 8 \mathrm{pmol} / 10^{6}$ cells in diabetics, as compared to $72 \pm 9$ and $110 \pm 9 \mathrm{pmol} / 10^{6}$ cells in normals. At concentrations of glucagon that are maximally efficient $(\geqslant 7 \mathrm{nmol} / 1)$ cyclic AMP production was higher in diabetic $\left(202 \pm 20 \mathrm{pmol} / 10^{6}\right.$ cells $)$ than in normal rats $\left(156 \pm 7 \mathrm{pmol} / 10^{6}\right.$ cells $)$. Thus, diabetes seems to increase the quantity of adenylate cyclase and decrease its affinity for glucagon. Those changes are not related to a modification of the glucagon binding sites and are associated to an increase of insulin receptors.

\footnotetext{
$\overline{1}$ Transcribed in the previous publications as Tchamras
}

Key words: Hepatocytes, streptozotocin-treated rats, normal rats, insulin receptors, glucagon receptors, cyclic AMP production.

Changes in specific binding of insulin and glucagon have been observed in experimental diabetic animals. The number of insulin receptors in liver membranes from streptozotocin diabetic rats is increased, and is associated with hypoinsulinaemia $[1,2]$. Similar observations have been made in diabetic Chinese hamsters [3]. In contrast, studies of glucagon binding in diabetic rat liver membranes have yielded contradictory results $[1,2,4]$. Davidson et al. reported no change in glucagon binding [1] while other authors found a decreased [4] or an increased [2] glucagon binding to liver membranes of streptozotocin-treated rats. This has prompted us to investigate the early steps of glucagon action in experimental diabetes, using isolated liver cells. In each animal, the binding of insulin by liver cells was determined as a control of receptor modification due to diabetes. The characteristics of glucagon receptors regarding the kinetics and stoichometry of the binding process were simultaneously measured in comparative experiments.

\section{Materials and Methods}

\section{Animals}

Male Sprague-Dawley rats (Iffa Credo) weighing 120-130 g were fed ad libitum on a standard laboratory diet, and were given free access to water. Diabetes was induced in rats fasted overnight by a single IV injection of streptozotocin $(65 \mathrm{mg} / \mathrm{kg})$ in $0.1 \mathrm{~mol} / \mathrm{l}$ citrate buffer, $\mathrm{pH}$ 4.0. Control rats received the diluent only. The streptozotocin-treated rats developed glycosuria and hyperglycaemia 
within $48 \mathrm{~h}$ after injection. The animals were sacrificed 7 days later, when blood glucose levels were higher than $400 \mathrm{mg} / 100 \mathrm{ml}$. All animals were studied in the fed state and sacrificed at about $10 \mathrm{~h}$.

\section{Materials}

Highly purified porcine insulin (MCS 821506 ) and porcine glucagon (B 66) were used for iodination and as standards (generously supplied by Dr. J. Schlichtkrull, Novo Research Institute, Copenhagen). Carrier free $\mathrm{Na}^{125} \mathrm{I}$, IMS 300, was purchased from the Radiochemical Centre (Amersham, England), bovine serum albumin (BSA, fraction V, lot 294) from Miles Laboratories, crude collagenase (type I, $140 \mathrm{IU} / \mathrm{mg}$, lot $86 \mathrm{C} 0075$ ) from Sigma, N-2 hydroxymethyl piperazide N'2 ethane-sulfonic acid (HEPES, lot 28c-5026) from Sigma, and streptozotocin (lot 9681-GGS $118 \mathrm{~F}$ IU 9889) from Upjohn Laboratories. The 2'0-succinyl cyclic AMP (cyclic-Suc-AMP), its tyrosine methyl ester (cyclic-Suc-AMP-tyr$0-\mathrm{Me}$ ), the radioiodinated derivative ( ${ }^{125} \mathrm{I}$-labelled-cyclic-SucAMP-tyr-0-Me) and antibodies against the albumin-conjugated cyclic-Suc-AMP were prepared in our laboratory [5, 6]. Cyclic AMP, AMP, ADP, ATP, adenosine were purchased from Calbiochem, bacitracin (lot 124c, 01841) from Sigma, trasylol (R) (6600 IKIU/mg) from Bayer AG, and 3-isobutyl-l-methylxanthine, IBMX (lot 121247) from Aldrich Chemical Company Inc. The guinea pig anti-porcine insulin and rabbit anti-porcine glucagon sera were prepared in our laboratory. Caffeine and other chemicals were obtained from Merck.

\section{Isolation of Liver Cells}

The method of liver cell preparation was the "two-step procedure" described by Seglen involving a perfusion of liver with a calcium free buffer followed by perfusion with collagenase [7, 8]. The following modifications of that procedure were made: 1) collagenase buffer $100 \mathrm{ml}$, containing $50 \mathrm{mg}$ collagenase, was supplemented with $5 \mathrm{mg}$ of soybean trypsin inhibitor (Sigma) [9]; 2) after collagenase digestion, the liver was immediately flushed to remove collagenase with 100 to $150 \mathrm{ml}$ of calcium and magnesium free Krebs Ringer Phosphate (KRP), pH 7.5, containing $0.2 \mathrm{~g} / 100 \mathrm{ml}$ bovine serum abumin (BSA) dialysed (against KRP): 3 ) once separated, the cells were centrifuged at $200 \mathrm{rpm}$ for $1 \mathrm{~min}$. The cell pellet was washed in KRP containing $3 \mathrm{~g} / 100 \mathrm{ml}$ BSA, pH 7.5. Following the third centrifugation the purified parenchymal cell pellet was resuspended in fresh incubation medium (KRP $3 \mathrm{~g}$ / $100 \mathrm{ml}$ BSA, pH 7.5) at a concentration of 800000 cells $/ \mathrm{ml}$. Cells were counted in a Malassez haemocytometer. This procedure yielded 400 to $500 \times 10^{6}$ cells/liver.

The viability of the cells was similar in diabetic and control animals. The proportion of cells excluding Trypan Blue was about $90-95 \%$ before incubation and not lower than $80 \%$ after $4 \mathrm{~h}$ at $20^{\circ}$ C. Extracellular lactic dehydrogenase activity [10] was not significantly increased after $2 \mathrm{~h}$ incubation in either diabetic $(4.5 \pm$ $1.0 \%$ vs $5.5 \pm 1.0 \%$ ) or control ( $4 \pm 1 \%$ vs $5 \pm 2 \%$ ) rat liver cells. The ATP content [11] of the diabetic and control hepatocytes was respectively $18 \pm 3$ and $18 \pm 2 \mathrm{nmol} / 10^{6}$ cells before incubation and $14 \pm 5$ and $14 \pm 2 \mathrm{nmol} / 10^{6}$ cells after $2 \mathrm{~h}$ incubation at $20^{\circ} \mathrm{C}$.

\section{Hormone Binding Assay}

${ }^{125} \mathbf{I}$-insulin and ${ }^{125} \mathbf{I}$-glucagon were monoiodinated, using the chloramine-T method under the conditions previously described $[12,13]$. The specific activity of labelled insulin and glucagon was 350 and $600 \mathrm{Ci} / \mathrm{g}$, respectively. Studies of insulin and glucagon binding were performed at $20^{\circ} \mathrm{C}$ in calcium-free KRP buffer as previously described [14] with the following modifications. Each incubation tube contained in a final volume of $0.5 \mathrm{ml},{ }^{125} \mathrm{I}$-labelled hormone at about $0.3 \mathrm{nmol} / 1$, unlabelled hormone at the concentrations indicated in the figures, BSA at $3 \mathrm{~g} / 100 \mathrm{ml}$ and $0.5 \times 10^{6}$ cells $/ \mathrm{ml}$. The medium of the cells incubated with glucagon also contained $2,000 \mathrm{IU} / \mathrm{ml}$ of kailikrein inhibitor (Trasylol) and $100 \mu \mathrm{g} / \mathrm{ml}$ of bacitracin [15] as inhibitors of glucagon degradation, $0.1 \mathrm{mmol} / 1$ of IBMX, a potent inhibitor of phosphodiesterase activity, and $10 \mathrm{mmol} / \mathrm{l}$ of alanine. The cell bound hormone was separated by centrifugation as described previously $[16,17]$. The supernatant was removed and the radioactivity of the washed pellet was determined by gamma spectrometry.

\section{Hormone Degradation Assay}

Hormone degradation was measured by the method previously described [18]. ${ }^{125}$ I-labelled hormone $(0.3 \mathrm{nmol} / \mathrm{l})$ was exposed to liver cells of control and diabetic rats. After $2 \mathrm{~h}$ incubation at $20^{\circ} \mathrm{C}$, the ${ }^{125} \mathrm{I}$-labelled hormone remaining intact in the medium was tested for its ability to rebind to specific receptors in liver membranes. Appropriate controls without cells represented $100 \%$ of the substrate available for degradation.

\section{Measurement of Cyclic AMP}

Endogenous cyclic AMP was measured by radioimmunoassay in the methanol extract of the whole mixture (cells + medium) as previously described [19]. For concentrations lower than $20 \mathrm{nmol} / 1$ the sensitivity of the radioimmunoassay was increased by the succinylation of the cyclic AMP following the method described by Cailla et al. [20].

\section{Other Determinations}

Plasma immunoreactive glucagon was measured using the Unger glucagon antibody $30 \mathrm{~K}$ [21]. Plasma insulin concentration was estimated by radioimmunoassay $[22,23]$, the results being expressed in terms of a porcine insulin standard $(20 \mathrm{IU} / \mathrm{mg})$. Plasma glucose was determined by the glucose oxidase method (Boehringer Mannheim Test, FRG). Protein concentration was measured by the method of Lowry et al. using BSA as standard [24].

\section{Expression of Results}

Specific binding was obtained by subtracting from the total binding the amount of labelled hormone which is not displaced by a large excess of unlabelled hormone $(17 \mu \mathrm{mol} / \mathrm{l}$ for insulin and $14 \mu \mathrm{mol} / \mathrm{l}$ for glucagon). The number of specific binding sites of the hormone-receptor complexes was obtained from competition data at steady state by plotting the amount of hormone specifically bound against the concentration of free hormone. The number of binding sites and the corresponding apparent dissociation constant were also determined by Scatchard plots of the same data. Results were expressed by mean \pm SEM. Statistical analysis was performed by using Student's unpaired t-test. In some instances Wilcoxon's test for coupled differences was used.

\section{Results}

\section{Experimental Animals}

The presence of diabetes, 7 days after injection of streptozotocin was attested in each animal by gly- 
Table 1. Characteristics of the control and diabetic rats. Measurements were performed 7 days after injection of streptozotocin ( $65 \mathrm{mg} / \mathrm{kg})$

\begin{tabular}{llllll}
\hline & $\begin{array}{l}\text { Body weight } \\
\mathrm{g}\end{array}$ & $\begin{array}{l}\text { Glycosuria } \\
\mathrm{g} / \mathrm{l}\end{array}$ & $\begin{array}{l}\text { Plasma glucose } \\
\mathrm{mg} / 100 \mathrm{ml}\end{array}$ & $\begin{array}{l}\text { Plasma insulin } \\
\mathrm{mU} / \mathrm{l}\end{array}$ & $\begin{array}{l}\text { Plasma glucagon } \\
\mathrm{ng} / \mathrm{l}\end{array}$ \\
\hline $\begin{array}{l}\text { Controls }(\mathrm{n}=8) \\
\begin{array}{l}\text { Streptozotocin } \\
\text { treated rats }(\mathrm{n}=8)\end{array}\end{array}$ & $169 \pm 3$ & not detectable & $161 \pm 3$ & $100 \pm 11$ & $335 \pm 41$ \\
\hline
\end{tabular}

${ }^{\mathrm{a}} \mathrm{p}<0.001$

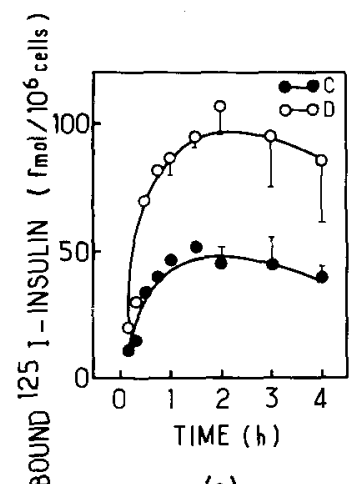

(a)

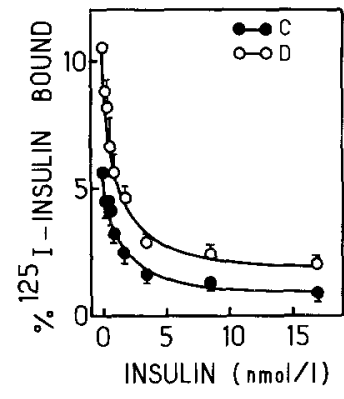

(b)

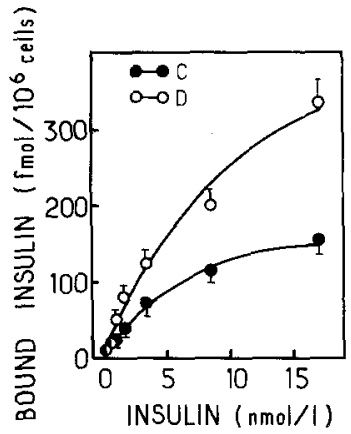

(c)

Fig. 1. Time-course $\mathbf{a}$ and competition curve b of insulin binding to isolated hepatocytes from control (C) and diabetic (D) rats. Incubation conditions were as described under Methods. Each point is the mean \pm SEM of 4 separate cell preparations for control and diabetic rats. The panel $\mathbf{c}$ represents at each hormone concentration, the amount of insulin bound, calculated from the competition curve

cosuria, loss of body weight, high plasma glucose level, low plasma insulin and high plasma glucagon (Table 1).

\section{Effect of Diabetes on Insulin Binding}

The binding of ${ }^{125} \mathrm{I}$-insulin increased with time in cells of control and diabetic rats (Fig. 1 a). In diabetic rats, the specific binding of ${ }^{125} \mathrm{I}$-insulin was about two-fold greater than in control rats. As insulin binding was maximal and stable in both groups between 60 and 180 min of incubation, the binding of ${ }^{125} \mathrm{I}$-insulin was studied as a function of increasing unlabelled hormone concentration after $120 \mathrm{~min}$ incubation (Fig. $1 \mathrm{~b})$. The initial binding was $5.7 \pm 1.3 \%(\mathrm{n}=4)$ and $10.8 \pm 2.0 \%(\mathrm{n}=4)$ of the total ${ }^{125}$ I-insulin with cells from control and diabetic rats, respectively. The $50 \%$ inhibition of ${ }^{125} \mathrm{I}$-insulin binding was achieved with about $1.25 \mathrm{nmol} / \mathrm{l}$ insulin in both types of cells, suggesting an identical affinity.

When the data were expressed as quantities of insulin bound per $10^{6}$ cells (Fig. $1 \mathrm{c}$ ) hepatocytes of diabetic rats bound about twice as much insulin as those of controls $(\mathrm{p}<0.05)$. At $0.6 \mathrm{nmol} / 1(4 \mathrm{ng} / \mathrm{ml})$ the quantity of insulin bound was $42.2 \pm 6.5(n=4)$ and $26.4 \pm 6.0(\mathrm{n}=4) \mathrm{fmol} / 10^{6}$ cells in diabetic and control rats, respectively.

To determine whether the increased insulin binding in the cells of diabetic rats was due to an increased affinity or to a higher number of receptor sites, the binding data were analyzed by the method of Scatchard [25]. The curves obtained for diabetic and control rats were curvilinear and parallel (data not shown), suggesting that the binding affinity for insulin was similar. The number of occupied binding sites was significantly higher in diabetics than in controls at both concentrations tested. The number of molecules of insulin bound per liver cell of control rats, calculated from data shown in Figure 1, at 0.3 or $17.8 \mathrm{nmol} / 1$ insulin were $1800 \pm 350$ and $93000 \pm 7600$, respectively. The corresponding numbers in streptozotocin-treated rats were $3400 \pm 500$ and $205000 \pm 5000$, respectively.

To rule out the possibility that increased insulin binding in diabetic rats could have been due to decreased hormone degradation, the degradation of insulin by hepatocytes was examined. There was no significant difference in the amount of insulin degraded by hepatocytes of control and diabetic rats. After $2 \mathrm{~h}$ incubation at $20^{\circ} \mathrm{C}$, the percent intact ${ }^{125} \mathrm{I}$ insulin was $81 \pm 2 \%$ and $75 \pm 4 \%(n=4)$ in control and diabetic rats, respectively.

\section{Effect of Diabetes on Glucagon Binding and Glucagon-stimulated Cyclic AMP Accumulation}

Glucagon binding was time dependent in control and diabetic rats (Fig. 2a). In both these groups maximal binding was attained by $45 \mathrm{~min}$ and apparent equilibrium was maintained until $240 \mathrm{~min}$. The quantity of 


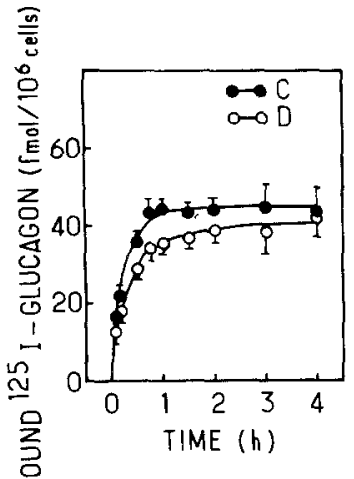

(a)

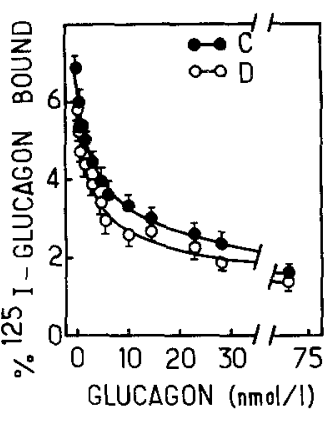

(b)

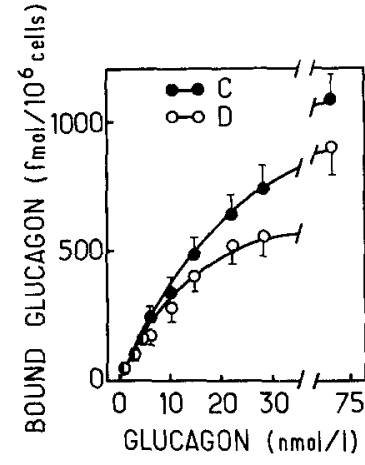

(c)
Fig. 2. Time-course a and competition curve b of glucagon binding to isolated hepatocytes from control (C) and diabetic (D) rats. Incubation conditions were described under Methods. Each point is the mean \pm SEM of 10 separate cell preparations for control and diabetic rats. In panel $\mathbf{c}$ the amount of glucagon bound, calculated from the competition curve was plotted as a function of hormone concentrations

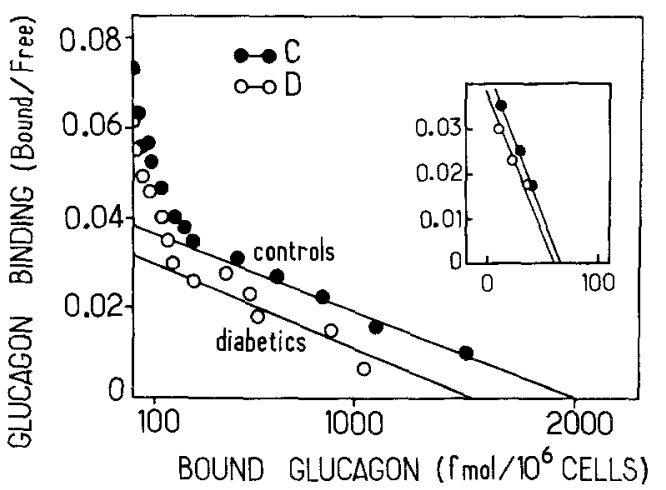

Fig. 3. Scatchard analysis of glucagon to hepatocytes from control (C) and diabetic (D) rats. The ratio of bound to free glucagon (B/F) was plotted as a function of bound glucagon (B) (Data from Fig. 2b). The inset represents the points corresponding to the high affinity binding sites, obtained by subtraction from the total sites the contribution of the low affinity binding sites

Table 2. Dissociation constants and number of glucagon binding sites per liver cell calculated from data shown in Figure 3

\begin{tabular}{|c|c|c|c|}
\hline & & \multicolumn{2}{|c|}{ Glucagon binding sites } \\
\hline & & High affinity & Low affinity \\
\hline $\begin{array}{l}\text { Dissociation constant }(\mathrm{Kd}) \\
\left(\mathrm{mol} / 1 \times 10^{-9}\right)\end{array}$ & $\begin{array}{l}\mathrm{C} \\
\mathrm{D}\end{array}$ & $\begin{array}{l}2.4 \pm 0.2 \\
2.5 \pm 0.3\end{array}$ & $\begin{array}{l}52 \pm \\
50 \pm\end{array}$ \\
\hline $\begin{array}{l}\text { Number of sites per cell } \\
\left(\times 10^{3}\right)\end{array}$ & $\begin{array}{l}\mathrm{C} \\
\mathrm{D}\end{array}$ & $\begin{array}{l}51 \pm 2 \\
45 \pm 5\end{array}$ & $\begin{array}{l}1,300 \pm 134 \\
1,000 \pm 167\end{array}$ \\
\hline
\end{tabular}

bound ${ }^{125} \mathrm{I}$-glucagon in diabetic hepatocytes was not significantly different from controls. Binding of glucagon was studied in the presence of increasing concentrations of unlabelled hormone ( 1 to $75 \mathrm{nmol} / 1$ ) (Fig. 2b). The amount of ${ }^{125}$ I-glucagon bound after a $60 \mathrm{~min}$ incubation period was $6.8 \pm 0.4 \%(\mathrm{n}=10)$ and $5.8 \pm 0.5 \%(\mathrm{n}=10)$ in control and diabetic rat liver cells, respectively. The $50 \%$ inhibition of the
${ }^{125}$ I-glucagon binding was achieved with about $7 \mathrm{nmol} / 1$ glucagon in both conditions. This suggests that the apparent average affinity is similar in both cases. The amount of glucagon bound at equilibrium was calculated from the competition curve and was not significantly different in diabetics and controls (Fig. $2 \mathrm{c})$. At $0.1 \mathrm{nmol} / \mathrm{l}(0.3 \mathrm{ng} / \mathrm{ml})$ glucagon, a concentration close to that present in portal vein of normal rat [26], the quantity of bound glucagon was 12.4 $\pm 3.0(\mathrm{n}=10)$ and $10.2 \pm 2.0(\mathrm{n}=10) \mathrm{fmol} / 10^{6}$ cells in control and diabetic rats, respectively.

Scatchard analysis of the same data (Fig. 3) showed that diabetic and control curves were curvilinear and parallel to each other, indicating that the binding affinities for glucagon were similar in diabetic and control hepatocytes (Table 2). Neither was the degradation of labelled glucagon significantly different. After $60 \mathrm{~min}$ of incubation at $20^{\circ} \mathrm{C}$, the percent intact ${ }^{125} \mathrm{I}$-glucagon was $86 \pm 5.5 \%$ and $82 \pm$ $6.4 \%$ in control and diabetic rats, respectively.

The glucagon-stimulated cyclic AMP accumulation was studied at $20^{\circ} \mathrm{C}$ in the presence of $0.1 \mathrm{mmol} / 1$ IBMX. These conditions are optimal for relating the accumulation of cyclic AMP to the activation of adenylate cyclase by glucagon. In these conditions, the rate of cyclic AMP production induced by glucagon was constant between 0 and $10 \mathrm{~min}$ in diabetics and in controls (Fig. 4, left panel). After $30 \mathrm{~min}$ a plateau of cyclic AMP level induced by glucagon was observed. In both groups, the addition of 3 -isobutyl1 -methylxanthine at a concentration higher than $0.1 \mathrm{mmol} / 1 \mathrm{did}$ not result in any further stimulation of cyclic AMP by glucagon (Fig. 4, right panel), suggesting maximal inhibition of phosphodiesterase activity.

The mean dose-response curves to glucagon are shown in Figure 5. In the absence of glucagon the level of cyclic AMP did not differ significantly in control $\left(5.7 \pm 0.7 \mathrm{pmol} / 10^{6}\right.$ cells, $\left.\mathrm{n}=10\right)$ and diabetic $\left(6.5 \pm 1.0 \mathrm{pmol} / 10^{6}\right.$ cells, $\left.\mathrm{n}=10\right)$ liver cells. After 
addition of glucagon the following was observed: 1) Cyclic AMP response to concentrations of glucagon below $1 \mathrm{nmol} / 1$ was lower in diabetics than in normals: for $0.3 \mathrm{nmol} / 1$ and $0.6 \mathrm{nmol} / 1$ of glucagon, cyclic AMP production was $48 \pm 7$ and $78 \pm 8 \mathrm{pmol} /$ $10^{6}$ cells in diabetics, as compared to $72 \pm 9$ $(\mathrm{p}<0.05)$ and $110 \pm 9 \mathrm{pmol} / 10^{6}$ cells in normals $(p<0.05)$. 2) At concentrations of glucagon that are maximally efficient cyclic AMP production was higher in diabetic than in normal rats; for example at $7 \mathrm{nmol} / 1$ glucagon cyclic AMP production was $202 \pm$ $20 \mathrm{pmol} / 10^{6}$ cells and $156 \pm 7 \mathrm{pmol} / 10^{6}$ cells $(\mathrm{p}<0.05)$, respectively. 3) Half-maximum glucagoninduced cyclic AMP level was generated by a concentration of glucagon which was about 3 times higher than that observed in controls.

When the glucagon-stimulated cyclic AMP accumulation is compared to the percentage of glucagon bound at steady state (Fig. 6), it is apparent that most cyclic AMP accumulation occurred when only a fraction of the glucagon binding sites was occupied. Furthermore, for a proportion of glucagon bound ranging from 2 to $30 \%$, the percentage of the cyclic AMP accumulation was lower in cells of diabetic rats than those of controls (Fig. 6).

\section{Discussion}

The data reported here indicate that in streptozotocin diabetes, glucagon-induced cyclic AMP production in liver cells is decreased without significant change in the number or in the affinity of the glucagon binding sites. This decrease is observed at concentrations of glucagon in the range of those found in the portal vein of the rat [26], dog [33] and man [34], concentrations that are estimated not to exceed $1.7 \times$ those found peripherally. The validity of our results is strengthened by the following: 1) the isolated cell preparation from both diabetic and control rat liver consisted of about $90 \%$ single hepatocytes with well preserved structure as judged by the phase microscopy, their ability to exclude Trypan Blue, and absence of leakage of intracellular lactic dehydrogenase; 2) the inactivation of ${ }^{125} \mathrm{I}$-glucagon and the degradation of receptors were minimized by performing the incubation at $20^{\circ} \mathrm{C} ; 3$ ) in accordance with data from different laboratories $[1,2,3]$, the insulin binding capacity was significantly higher in diabetic animals than in controls in our experimental conditions (Fig. 1).

Studies of glucagon binding in streptozotocin diabetic rats have presented contradictory results. A two-fold decrease [4] and a 95\% increase [2] of the binding capacity for glucagon to liver plasma mem-
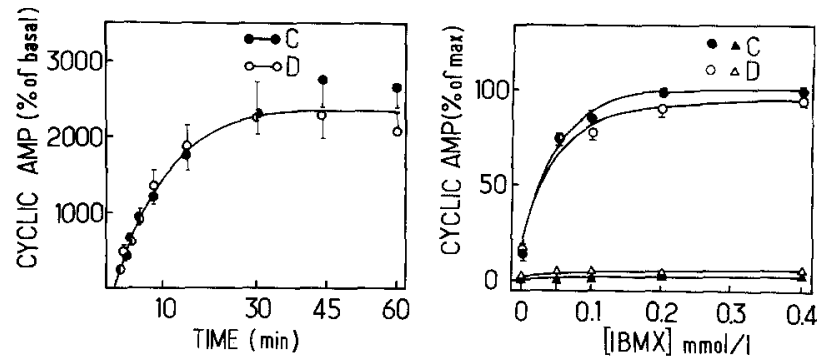

Fig. 4. Left panel: Time-course of glucagon-stimulated cyclic AMP accumulation in isolated liver cells from control (C) and diabetic (D) rats. The cyclic AMP level is expressed as percent of the basal value. The basal level is $100 \pm 13(\mathrm{n}=10)$ for control and $100 \pm$ $26(\mathrm{n}=10)$ for diabetic rats. Right panel: The cyclic AMP accumulation after $30 \mathrm{~min}$ of incubation is plotted as a function of the IBMX concentration. Each point is the mean \pm SEM of 3 separate experiments. In both studies, cells $\left(0.5 \times 10^{6} / \mathrm{ml}\right)$ were incubated at $20^{\circ} \mathrm{C}$ in the absence or in the presence of $1 \mathrm{nmol} / \mathrm{l}$ of glucagon. The incubation buffer was identical to that used for glucagon binding assay (see Methods)

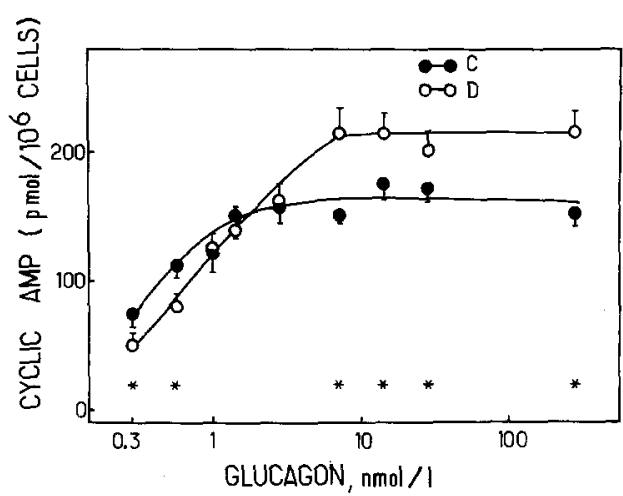

Fig. 5. Dose-response of glucagon-stimulated cyclic AMP accumulation in liver cells of control (C) and diabetic (D) rats. Cells $(0.5$ $\times 10^{6} / \mathrm{ml}$ ) were exposed to various concentrations of glucagon and incubated for $30 \mathrm{~min}$ at $20^{\circ} \mathrm{C}$. Each point is the mean \pm SEM of 10 separate experiments. *, $\mathrm{p}<0.05$ between diabetic and control rats

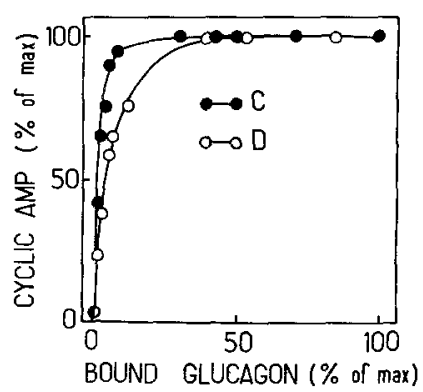

Fig. 6. Relationship between glucagon-stimulated cyclic AMP accumulation (Fig. 5) and glucagon specifically bound to isolated liver cells (Fig. 2b) from control (C) and diabetic (D) rats 
branes of diabetic rats have been reported. These discrepancies may be due to differences that occur in the preparation of liver plasma membranes. Indeed, as reported [2], membranes from untreated diabetic rat differ from normal in terms of enzymatic activities, namely of 5' nucleotidase and glucose-6phosphatase. Furthermore, it has been demonstrated that the receptor protein content of cell membranes does not necessarily reflect the hormone binding by intact hepatocytes [27].

To our knowledge, the only previous study on glucagon binding to diabetic hepatocytes was presented by Bhathena et al. [28]. These authors reported that glucagon binding was decreased about two-fold in diabetic rats compared to controls, whereas no significant change was found in our studies. Severity of diabetes was similar in the two studies. However, Bhathena et al. [28] studied glucagon binding after $30 \mathrm{~min}$ incubation at $30^{\circ} \mathrm{C}$. Their data indicated that in these conditions no alteration in glucagon degradation occurred in diabetic rat hepatocytes compared to normal rats when tested by the rebinding of glucagon to charcoal. In our study under similar experimental conditions, the exact measurement of the binding capacity of glucagon at $30^{\circ} \mathrm{C}$ was difficult. No steady state of binding was obtained and the degradation of glucagon after $30 \mathrm{~min}$ incubation was as high as $50 \%$, when measured by the rebinding of the glucagon to plasma membranes. Since in such conditions the comparative study of the hormone binding was meaningless, the experiments were performed at $20^{\circ} \mathrm{C}$. In that respect, we have verified that the number of binding sites of normal hepatocytes was much higher at $20^{\circ} \mathrm{C}$ (data not shown) in accordance to the results obtained by Sonne et al. [29].

Our data on the number of insulin binding sites are in agreement with others $[1,2,3,28]$ who have observed an increase in diabetes with low plasma insulin levels. Such results are consistent with the observation that an inverse correlation exists between insulin binding and the circulating hormone concentration [30, 31]. However, our data on glucagon binding does not support the possibility of a down regulation of glucagon receptors related to the high plasma glucagon level present in the streptozotocin diabetic rats. Such a down regulation mechanism has been observed with fasting, where the high plasma glucagon level is associated with a significant decrease of glucagon binding [32]. However, the hyperglucagonaemia in fasting is of short duration as compared to that of diabetic state. It will be noted that even in the studies that reported a decrease in glucagon receptors in association with hyperglucagonaemia [4], no correlation was found between the plasma glucagon level and the reduction in receptor concentration.

The glucagon-stimulated cyclic AMP production in liver cells was studied in the conditions that are optimal for relating the cyclic AMP level to activation of adenylate cyclase. Most, if not all, the phosphodiesterase activity was inhibited by lowering the temperature to $20^{\circ} \mathrm{C}$ and with addition of IBMX. Our results clearly demonstrated that streptozotocin diabetes affects the glucagon-induced cyclic AMP production in liver cells. They also indicate that the concentration of glucagon used and its efficiency, the magnitude of glucagon-induced stimulation, are not affected in the same way. Briefly, the potency of glucagon is lower and the efficiency of glucagon is higher in liver cells of diabetics compared to controls. Such data may explain the apparent discrepancy in results that indicate an increase [2] or a decrease [28] of the glucagon-induced cyclic AMP accumulation, or the adenylate cyclase activity, in diabetic liver. The higher efficiency of glucagon in diabetics suggests that the quantity of adenylate cyclase is increased in the liver cells of diabetics. Our observation that low concentrations of glucagon are less potent in promoting cyclic AMP production in liver cells of diabetics than in those of controls strongly suggests a decrease in the affinity of adenylate cyclase for glucagon. The number of the binding sites being unaltered, the decrease in affinity could be related to a defect beyond the binding process.

The abnormality of the early steps of glucagon action observed in diabetes is different to that found in fasting animals. In fasting state, the decrease in the glucagon-induced cyclic AMP is related to a decrease in the number of glucagon binding sites [32], and the effect of hyperglucagonemia is counterbalanced by the persistance of insulin production. In diabetes, the increased number of insulin binding sites may partially balance the lack of insulin. Such regulation is not evident for glucagon. However, the diminished sensitivity of the diabetic liver cells to glucagon can provide a mechanism for reducing to some extent the excessive gluconeogenesis and hyperglycaemia associated with the diabetic state.

Acknowledgements. We are grateful to Mrs. C. Rouyer-Fessard for her excellent technical help and to Mrs. F. Gespach and Miss C. Brunet for the careful preparation of the manuscript. This work was supported by the Institut National de la Santé et de la Recherche Médicale (INSERM) (grant $n^{\circ} 7750434$ ).

\section{References}

1. Davidson MB, Kaplan SA (1977) Increased insulin binding by hepatic plasma membranes from diabetic rats. Normalization by insulin therapy. J Clin Invest 59: 22-30 
2. Soman V, Felig P (1978) Glucagon binding and adenyl cyclase activity in liver membranes from untreated and insulin-treated diabetic rats. J Clin Invest 61: 552-506

3. Hepp KD, Langley J, Von Funcke HJ, Renner R, Kemmler W (1975) Increased insulin binding capacity of liver membranes from diabetic Chinese hamsters. Nature 258: 154

4. Srikant CB, Freeman D, McCorkle K, Unger RH (1977) Binding and biologic activity of glucagon in liver cell membranes of chronically hyperglucagonemic rats. J Biol Chem 252: 7434-7436

5. Broer Y, Fouchereau M, Rosselin G (1972) Dosage radioimmunologique de l'AMPc et du GMPc. Préparation, purification et contrôle de 2'0 succinyl-AMP 3'5' cyclique et du 2'0 succinyl-GMP 3'5' cyclique. C R Acad Sci [D] Paris 275: 619-622

6. Broer Y, Lhiaubet-Grapin AM, Rosselin G (1972) Dosage radio-immunologique de l'AMP 3'5' cyclique. Préparation, purification et contrôle du tyrosine-succinyl-AMPc et de son dérivé iodé. C R Acad Sci [D] Paris 275: 883-886

7. Seglen PO (1972) Preparation of rat liver cells. Exp Cell Res 74: $450-454$

8. Seglen PO (1973) Preparation of rat liver cells. Exp Cell Res 76: $25-30$

9. Crane LJ, Miller DL (1974) Synthesis and secretion of fibrinogen and albumin by isolated rat hepatocytes. Biochem Biophys Res Commun 60: 1269-1277

10. Neilands JB (1955) Lactate dehydrogenase of heart muscle. Methods Enzymol 1: 449-452

11. Stanley PE, Williams SG (1969) Use of the liquid scintillation spectrometer for determining adenosine triphosphate by the luciferase enzyme. Anal Biochem 29: 381-392

12. Freychet P, Roth J, Neville DM Jr (1971) Monoiodoinsulin: Demonstration of its biological activity and binding to fat cells and liver membranes. Biochem Biophys Res Commun 43: 400-408

13. Nottey JJ, Rosselin G (1971) Monoidoglucagon: Préparation, isolement, identification, contrôle radio-immunologique. C R Acad Sci [D] Paris 273: 2118-2121

14. Freychet P, Rosselin G, Rançon F, Fouchereau-Péron M, Broer Y (1974) Interaction of insulin and glucagon with isolated rat liver cells. I. Binding of the hormones to specific receptors. Horm Metab Res (Suppl) 5: 72-78

15. Desbuquois B, Krug F, Cuatrecasas P (1974) Inhibitors of glucagon inactivation: Effect of glucagon receptor interaction and glucagon stimulated adenylate cyclase. Biochim Biophys Acta 343: 101-120

16. Rodbell M, Krans MJ, Pohl SL, Birnbaumer L (1971) The glucagonsensitive adenyl cyclase system in plasma membranes of rat liver. III. Binding of glucagon: Method of assay and specificity. J Biol Chem 246: 1861-1871

17. Freychet P, Roth J, Neville DM Jr (1971) Insulin receptors in the liver: Specific binding of ${ }^{125} \mathrm{I}$-insulin to the plasma membrane and its relation to insulin bioactivity. Proc Natl Acad Sci USA 68: 1833-1837

18. Freychet P, Kahn CR, Roth J, Neville DM Jr (1972) Insulin interactions with liver plasma membranes. Independence of binding of the hormone and its degradation. J Biol Chem 247: 3953-3961

19. Rosselin G, Freychet P, Fouchereau M, Rançon F, Broer Y (1974) Interactions of insulin and glucagon with isolated rat liver cells. II. Dynamic changes in the cyclic AMP induced by hormones. Horm Metab Res (Suppl) 5: 78-86
20. Cailla HL, Racine-Weisbuch MS, Delaage MA (1973) Adenosine $3^{\prime}-5^{\prime}$ cyclic monophosphate assay at $100^{-15}$ mole level. Anal Biochem 56: 394-407

21. Faloona GR, Unger RH (1972) Glucagon. In: Jaffe BM, Behrman HR (eds) Methods of hormone radioimmunoassay. Academic Press, New York, p 317-330

22. Rosselin G, Assan R, Yalow RS, Berson SA (1966) Separation of antibody-bound and unbound peptide hormones labeled with iodine 131 by talcum powder and precipitated silica. Nature 212: 355-357

23. Yalow RS, Berson SA (1960) Immunoassay of endogenous plasma insulin in man. J Clin Invest 39: 1157-1179

24. Lowry OH, Rosebrough NJ, Farr AL, Randall RJ (1951) Protein measurement with the Folin phenol reagent. J Biol Chem 193: $265-275$

25. Scatchard G (1949) The attractions of proteins for small molecules and ions. Ann NY Acad Sci 51: 660-672

26. Marre M, Bobbioni E, Suarez M, Reach G, Dubois MP, Assan $R$ (1979) Control of gastric glucagon secretion in the acutely pancreatectomized rat. Diabetes 29: 213-220

27. Almira EC, Reddy WJ (1979) Effect of fasting on insulin binding to hepatocytes and liver plasma membranes from rats. Endocrinology 104: 205-211

28. Bhathena SJ, Voyles NR, Smith S, Recant L (1978) Decreased glucagon receptors in diabetic rat hepatocytes. J Clin Invest 61: $1488-1497$

29. Sonne O, Berg T, Christophersen T (1978) Binding of ${ }^{125} \mathrm{I}$ labelled glucagon and glucagon-stimulated accumulation of adenosine 3'5'-monophosphate in isolated intact rat hepatocytes. J Biol Chem 253: 3203-3210

30. Gavin JR, Roth J, Neville DM Jr, De Meyts P, Buell DN (1974) Insulin-dependent regulation of insulin receptor concentrations: A direct demonstration in cell culture. Proc Natl Acad Sci USA 71: 84-88

31. Soll AH, Kahn CR, Neville DM Jr, Roth J (1975) Insulin receptor deficiency in genetic and acquired obesity. J Clin Invest 56: 769-780

32. Fouchereau-Péron M, Rançon F, Freychet P, Rosselin G (1976) Effect of feeding and fasting on the early steps of glucagon action in isolated rat liver cells. Endocrinology 98: $755-760$

33. Buchanan KD, Vance JE, Dinstyl K, Williams RH (1969) Effect of blood glucose on glucagon secretion in anesthetized dogs. Diabetes 18: 11-18

34. Blackard WG, Nelson NC, Andrews SS (1974) Portal and peripheral vein immunoreactive glucagon concentration after arginine or glucose infusions. Diabetes 23: 199-202

Received: September 25, 1979 ,

and in revised form: March 10, 1980

Dr. H. Chamras

Unité de Recherche de Diabétologie

et d'Etudes Radio-Immunologiques des Hormones Protéiques

INSERM U. 55

Hôpital Saint-Antoine

184 Rue du Faubourg Saint-Antoine

F-75012 Paris

France 